\title{
Orthosteric and Allosteric Ligands of Nicotinic Acetylcholine Receptors for Smoking Cessation
}

\author{
Tasnim S. Mohamed ${ }^{1}$, Selwyn S. Jayakar ${ }^{2}$ and Ayman K. Hamouda ${ }^{1,3 *}$ \\ ${ }^{1}$ Department of Pharmaceutical Sciences, College of Pharmacy, Texas A\&M Health Sciences Center, Kingsville, TX, USA, \\ ${ }^{2}$ Department of Neurobiology, Harvard Medical School, Boston, MA, USA, ${ }^{3}$ Department of Neuroscience and Experimental \\ Therapeutics, College of Medicine, Texas A\&M Health Sciences Center, Bryan, TX, USA
}

OPEN ACCESS

Edited by:

Firas H. Kobeissy,

University of Florida, USA

Reviewed by:

Adriaan W. Bruijnzeel, University of Florida, USA

Ali Eid,

Qatar University, Qatar

${ }^{*}$ Correspondence:

Ayman K. Hamouda

hamouda@tamhsc.edu

Received: 13 August 2015 Accepted: 06 November 2015 Published: 25 November 2015

Citation:

Mohamed TS, Jayakar SS and Hamouda AK (2015) Orthosteric and Allosteric Ligands of Nicotinic Acetylcholine Receptors for Smoking Cessation.

Front. Mol. Neurosci. 8:71. doi: 10.3389/fnmol.2015.00071
Nicotine addiction, the result of tobacco use, leads to over six million premature deaths world-wide per year, a number that is expected to increase by a third within the next two decades. While more than half of smokers want and attempt to quit, only a small percentage of smokers are able to quit without pharmacological interventions. Therefore, over the past decades, researchers in academia and the pharmaceutical industry have focused their attention on the development of more effective smoking cessation therapies, which is now a growing 1.9 billion dollar market. Because the role of neuronal nicotinic acetylcholine receptors (nAChR) in nicotine addiction is well established, nAChR based therapeutics remain the leading strategy for smoking cessation. However, the development of neuronal nAChR drugs that are selective for a nAChR subpopulation is challenging, and only few neuronal $\mathrm{nAChR}$ drugs are clinically available. Among the many neuronal nAChR subtypes that have been identified in the brain, the $\alpha 4 \beta 2$ subtype is the most abundant and plays a critical role in nicotine addiction. Here, we review the role of neuronal nAChRs, especially the $\alpha 4 \beta 2$ subtype, in the development and treatment of nicotine addiction. We also compare available smoking cessation medications and other $\mathrm{nAChR}$ orthosteric and allosteric ligands that have been developed with emphasis on the difficulties faced in the development of clinically useful compounds with high nAChR subtype selectivity. Keywords: smoking cessation, nicotine addiction, nicotinic acetylcholine receptor (nAChR), positive allosteric
modulator, drug development

\section{INTRODUCTION}

Tobacco smoking is considered the leading preventable cause of disease, disability, and death worldwide (WHO report on the global tobacco epidemic 2011). According to the recent report of the Center for Disease and Control and the 32nd tobacco-related Surgeon General's Report published in 2014, smoking remains the single largest cause of preventable disease and death in USA (Alberg et al., 2014). There are about 45 million smokers in the USA leading to more than 400,000 premature deaths and over $\$ 300$ billion in health care expenses and lost productivity each year. Smoking prevalence in USA has declined in the last 50 years, in part,

\footnotetext{
Abbreviations: ACh, acetylcholine; DA, dopamine; $\mathrm{GABA}_{\mathrm{A}} \mathrm{R}, \gamma$-aminobutyric acid type A receptor; $\mathrm{nAChR}$, nicotinic acetylcholine receptor; NAc, nucleus accumbens; NRTs, nicotine replacement treatments; VTA, ventral tegmental area.
} 
because of public awareness and governmental regulation that control tobacco use. However, smoking prevalence among adults with serious mental illness has increased 53\% (Evins et al., 2015). In addition, an estimated 16 million Americans suffer from tobacco-related illnesses and 126 million Americans are exposed to secondhand smoking. Lung cancer is the primary contributor to tobacco-related illnesses; however, tobacco smoking also increases the risk of coronary heart disease, stroke and chronic obstructive pulmonary disease (Surgeon General's Report, 2014).

Tobacco smoke contains hundreds of chemicals, many of which are known carcinogens; however, nicotine is the only component with known addictive properties (Wonnacott et al., 2005). The ventral tegmental area (VTA) dopaminergic (DA) neurons, which send projections to the nucleus accumbens (NAc) are highly implicated in rewarding and aversive effects of nicotine (Klink et al., 2001; Laviolette and van der Kooy, 2004; Kalamida et al., 2007; Changeux, 2010). Nicotine modulates the firing rate of VTA DA neurons and the levels of dopamine in the NAc by acting directly on nicotinic acetylcholine receptors (nAChRs) expressed on these neurons (Picciotto et al., 1995, 1998). Nicotine also indirectly modulates VTA DA neurons firing rate through binding to nAChRs on GABAergic and glutamatergic neurons projecting to the VTA (Mansvelder et al., 2002). In the absence of nicotine, VTA DA neurons are characterized by spontaneous singlespike firing (Gracem and Bunney, 1984). However, in the presence of nicotine, burst firing of VTA DA neurons can be observed which subsequently increase in the level of extracellular dopamine in the NAc (Nisell et al., 1994; Erhardt et al., 2002). With prolonged use of nicotine products, dopaminergic reward pathways become "sensitized" to nicotine and nicotine dependance becomes evident by the presence of withdrawal symptoms such as anxiety, irritability, and stress (Dome et al., 2010). Once nicotine dependance is developed, it requires continuous nicotine reinforcement and becomes difficult to quit smoking.

Neuronal-type nAChRs are pentameric ligand gated ion channels that mediate the action of the endogenous neurotransmitter acetylcholine. Twelve homologous neuronal nAChR subunits, nine $\alpha$ subunits $(\alpha 2-\alpha 10)$ and three $\beta$ subunits $(\beta 2-\beta 4)$, form functional $\mathrm{nAChRs}$ that are either homopentamers (e.g., $\alpha 7 \mathrm{nAChR}$ ) or heteropentamers (e.g., $\alpha 4 \beta 2$; Figure 1; Gotti and Clementi, 2004; Kalamida et al., 2007; Hurst et al., 2013). Each nAChR contains at least two orthosteric (agonist-binding, canonical) sites at the extracellular interface between an $\alpha$ subunit and a $\beta$ subunit (e.g., $\alpha 4: \beta 2$ interface) or between two $\alpha$ subunits (e.g., $\alpha 7: \alpha 7$ interface; Jensen et al., 2005). In addition to the orthosteric sites, allosteric binding sites have been identified within the extracellular and transmembrane domains of $\mathrm{nAChRs}$ (reviewed in Hamouda et al., 2014).

The $\alpha 4 \beta 2 \mathrm{nAChR}$ is the most abundant and diffuse neuronal $\mathrm{nAChR}$ subtype. It has a high affinity for nicotine $(K i, \sim 1 \mathrm{nM})$ representing $>90 \%$ of high-affinity nicotine binding sites in the brain and is a primary nAChRs subtype affected by nicotine blood levels achieved during smoking (Benwell et al., 1988; Flores et al., 1992; Rose et al., 1999; Sabey et al., 1999).
Chronic exposure of $\alpha 4 \beta 2 \mathrm{nAChR}$ to nicotine causes receptor desensitization and upregulation, which are thought to play key roles in nicotine reinforcement leading to addiction (Reus et al., 2007). Both $\alpha 4$ knock-out (KO) mice and $\beta 2 \mathrm{KO}$ mice lack the majority of high-affinity nicotine binding sites (Picciotto et al., 1995; Marubio et al., 1999). Alpha-4 KO mice display reduced antinociceptive effects of nicotine and lack the high-affinity nicotine-induced response in thalamic neurons (Marubio et al., 1999). Beta-2 KO mice do not self-administer nicotine, lack nicotine-induced improvement of performance in passive avoidance tests and exhibit no increase in VTA currents and striatal dopamine levels in response to nicotine (Picciotto et al., 1995, 1998). Targeted re-expression of the $\beta 2$ subunit in the VTA of mice lacking $\beta 2 \mathrm{nAChR}$ subunit $(\beta 2$ $\mathrm{KO}$ ) was sufficient to reestablish sensitivity to nicotine (Maskos et al., 2005). These results establish that $\alpha 4 \beta 2 \mathrm{nAChRs}$ in neurons, originating in the VTA, play a crucial role in nicotine addiction.

In addition to $\alpha 4$ and $\beta 2$, other nAChR subunits especially $\alpha 6$ and $\alpha 5$ have been shown to play a role in nicotine addiction, albeit as part of a $\beta 2$-containing receptors (Changeux, 2010; Brunzell et al., 2014). Alpha 6-containing nAChRs (e.g., $\alpha 6 \beta 2$ and $\alpha 4 \alpha 6 \beta 2$ ) are expressed in the VTA DA neuron cell bodies and thought to mediate $30-80 \%$ of nicotine-induced striatal and NAc dopamine release (Drenan et al., 2008; Exley et al., 2008; Zhao-Shea et al., 2011). An $\alpha 6 \mathrm{KO}$ mouse exhibits reduced burst firing of DA neurons and decreased nicotine self-administration (Changeux, 2010) suggesting a possible role in mediating changes in burst firing in DA neurons of the VTA. The $\alpha 5 \mathrm{nAChR}$ subunit is expressed in the reward pathway and forms a functional receptor with $\alpha 4$ and $\beta 2$ subunits replacing a $\beta 2$ subunit (Changeux, 2010; Jin et al., 2014). Alpha 5-containing nAChRs have been shown to regulate dopamine transmission in the dorsal striatum and to determine the aversive response to nicotine (Frahm et al., 2011; Exley et al., 2012). Furthermore, an $\alpha 5$ subunit variant containing a single aspartic acid to asparagine substitution ( $\alpha 5 \mathrm{D} 398 \mathrm{~N})$ is associated with an increased risk of developing nicotine dependance (Bierut et al., 2008). Because $\alpha 6-$ and $\alpha 5 \mathrm{nAChR}$ subunits have limited brain distribution compared with other $\mathrm{nAChR}$ subunits, targeting $\alpha 6-$ and $\alpha 5$-containing receptors is a promising strategy to develop tobacco cessation therapeutics with lower prevalence of adverse effects (Gotti et al., 2010).

\section{NICOTINE ADDICTION PHARMACOTHERAPIES}

Tobacco addiction is a chronic condition that in most cases requires a combination of behavioral and pharmacological therapies. The majority of smokers want $(69 \%)$ and attempt (52\%) to quit, however, only a small percentage of smokers succeed even with the help of currently available interventions (Gonzales et al., 2006). Because nAChRs play a central role in the neuronal mechanism leading to nicotine addiction, they are considered a major target for the development of therapeutic strategies for smoking cessation aids. Current FDA-approved therapeutic interventions for smoking cessation include nicotine, bupropion and varenicline (Figure 2). Other smoking cessation 


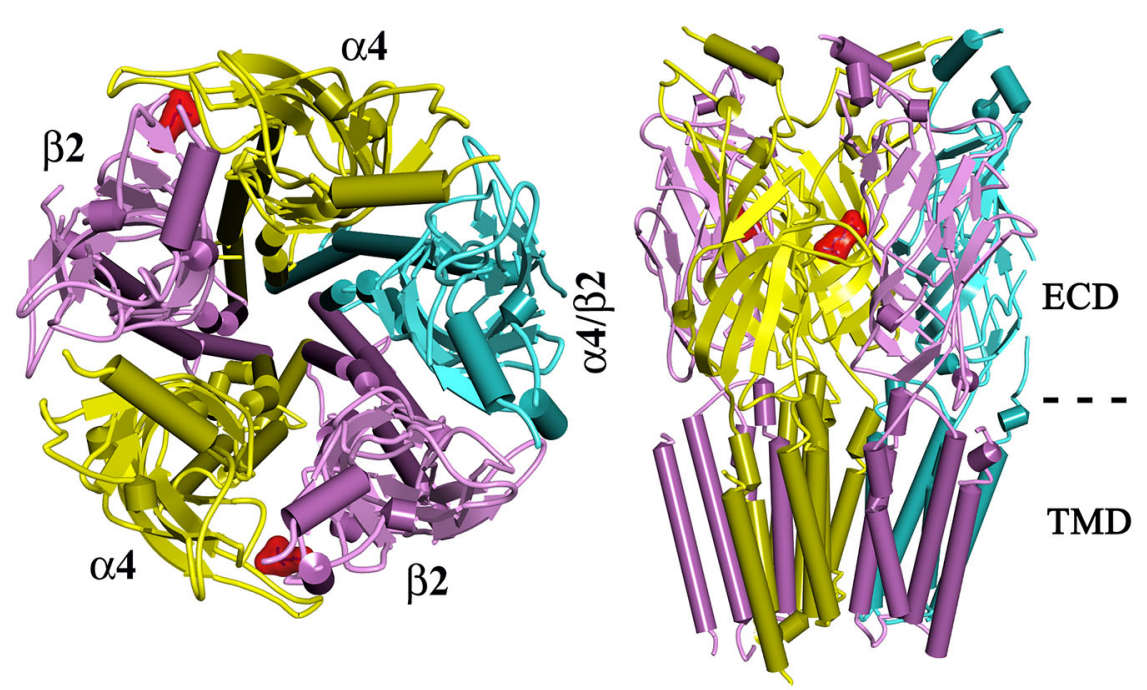

FIGURE 1 | A top view (left) and a side view (right) of a homology model of $\alpha \mathbf{4} \beta \mathbf{2}$ nAChR. The $\alpha 4 \beta 2$ nAChR contains two $\alpha 4$ subunits, two $\beta 2$ subunits, and a fifth subunit that can be $\alpha 4, \beta 2$, or other nAChR subunit. Two orthosteric (agonist-binding) sites are located at the extracellular domain of $\alpha 4$ and $\beta 2$ subunit (denoted by a docked ligand in red). ECD, extracellular domain; TMD, Transmembrane domain.

medications include cytisine as well as few second-line medications such as clonidine and nortriptyline (Lerman et al., 2007; Syad and Chaudhari, 2013).

\section{Nicotine Replacement Treatments}

Nicotine replacement treatments (NRTs) are FDA approved and the most prevalent pharmacological interventions for smoking cessation. NRT products include transdermal patches, chewing gums, nasal sprays, inhalers, orally dissolvable films, lozenges and low nicotine cigarettes. NRTs increase the chances of quitting when compared with placebo or a lack of treatment. However, over $90 \%$ of over-the-counter NRT users relapse within six months (Stead et al., 2008).

\section{Cytisine (Tabex ${ }^{\circledR}$ (EU); Sopharma/Extab)}

Cytisine is the world's oldest smoking cessation aid (Prochaska et al., 2013). It is an $\alpha 4 \beta 2 \mathrm{nAChR}$ partial agonist that is widely used in Europe for smoking cessation but not approved by the FDA for use in the United States. Cytisine has clinical efficacy (end-of treatment odd ratio of 1.93-3.4) that is comparable to varenicline and NRT but associated with higher frequency of adverse effects (Etter, 2006; West et al., 2011; Leaviss et al., 2014). When combined with behavioral support, cytisine was superior to NRT as a smoking cessation aid (Walker et al., 2014).

\section{Varenicline (Chantix ${ }^{\circledR}$ (USA), Champix ${ }^{\circledR}$ (EU); Pfizer)}

Varenicline is a cytisine derivative that acts as a partial agonist at $\alpha 4 \beta 2 \mathrm{nAChR}$ and a full agonist at $\alpha 7 \mathrm{nAChR}$, but its efficacy as a smoking cessation aid correlates with its effect on $\alpha 4 \beta 2$ nAChR (Mihalak et al., 2006; Rollema et al., 2007). Varenicline displays $\sim 30-60 \%$ of the in vivo efficacy of nicotine and blocks nicotine response both in vivo and in vitro
(Coe et al., 2005a). In randomized controlled trials, smokers receiving varenicline initially have higher abstinence rates than those receiving placebo or any other smoking cessation treatments (end-of-treatment odds ratio of 1.7-4.9; Tonstad et al., 2006; Reus et al., 2007; Nides et al., 2008). The abstinence rate was higher with longer varenicline treatment ( 24 vs. 6 weeks; Lee et al., 2008) but the superiority of varenicline compared with other treatments became less significant at longer end points (Gonzales et al., 2006). Along with cognitive behavioral therapy, varenicline improved prolonged abstinence rates for smokers with serious mental illnesses (Evins et al., 2014). Varenicline's association with behavioral side effects, including abnormal dreams, depression, and suicidal thoughts, led to the inclusion of boxed warnings for serious neuropsychiatric risks.

\section{Bupropion (Wellbutrin ${ }^{\circledR} /$ Zyban $^{\circledR}$; GlaxoSmithKline)}

Bupropion was used first as an antidepressant acting through the modulation of monoamine neurotransmitters and then it was approved by the FDA as the first non-nicotine medication for use in smoking cessation (Lerman et al., 2007). Bupropion inhibits $\alpha 4 \beta 2$ and $\alpha 7$ nAChRs, inhibits nicotine-induced dopamine release and attenuates nicotine self-administration (Slemmer et al., 2000; Dwoskin et al., 2006). Since adults with depression are more likely to smoke, the antidepressant effect of bupropion is very advantageous in decreasing stress and negative mood (dysphoric-like) state associated with nicotine withdrawal. Diminishing the dysphoric-like state associated with nicotine withdrawal is believed to prevent relapse to smoking and has been shown with other smoking cessation agents such as varenicline and cytisine (Igari et al., 2014). As monotherapy, bupropion has a lower abstinence rates compared with varenicline (Nides et al., 2008). However, in combination 
with varenicline, bupropion treatment has been shown to increase rates of long-term abstinence from smoking but not 7-day point prevalence at 12 and 26 weeks (Ebbert et al., 2014).

\section{INVESTIGATIONAL nAChR ORTHOSTERIC LIGANDS FOR SMOKING CESSATION}

Current tobacco dependance treatments have a 12-month abstinence success rate of $22 \%$ at best (Gonzales et al., 2006); the relapse rate within 1 year following the discontinuation of smoking cessation therapy is high (Tonstad et al., 2006). Therefore, a critical need for more effective smoking cessation aids still exists. Several nAChR ligands (partial agonists, antagonists, or desensitizers; Figure 2) are currently under clinical trials for use as smoking cessation therapies or have been discontinued during various phases of the trial.

\section{Cytisine Derivatives}

Cytisine has been used extensively as a template for nAChR ligands development (Cassels et al., 2005). In addition to varenicline, Pfizer has developed other cytisine derivatives which are nAChR partial agonists (CP-360288, CP-601927 and<smiles>CN1CCCC1c1cccnc1</smiles>

(1)<smiles>O=c1cccc2n1C[C@H]1CNC[C@H]2C1</smiles>

(3)<smiles>Cc1ncccc1OCC1CCCN1</smiles><smiles>OCCCCC#Cc1cncc(OCC2CCN2)c1</smiles><smiles>c1cnc2cc3c(cc2n1)CC1CNCC3C1</smiles><smiles>CNC(=O)Oc1ccc2c(c1)C1(C)CCN(C)C1N2C</smiles>

(6)

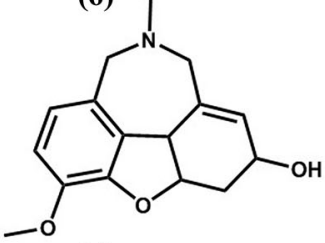

(7)
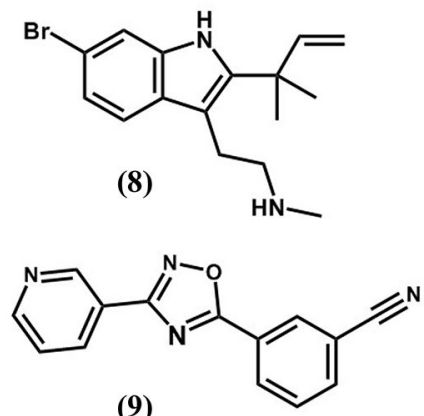

(9)

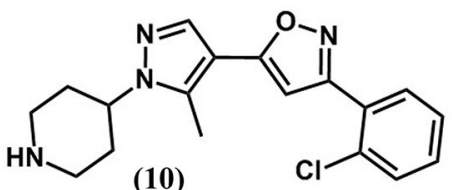

FIGURE 2 | The chemical structures of nAChR orthosteric (1-5) and allosteric (6-10) ligands. (1) nicotine; (2), cytisine; (3), varenicline;

(4), ABT-089; (5), sazetidine; (6), physostigmine; (7), galanthamine; (8), dFBr; (9), NS9283; (10), CMPI.
CP-601932) as part of its drug discovery programs targeting smoking cessation (Coe et al., 2005b). CP-601927 is a high affinity, selective partial agonist at the $\alpha 4 \beta 2 \mathrm{nAChR}$. In contrast, CP-601932 has similar affinity for $\alpha 4 \beta 2$ and $\alpha 3 \beta 4$ nAChRs with very low efficacy (2\%) at $\alpha 4 \beta 2 \mathrm{nAChRs}$ rendering it as functional antagonist of $\alpha 4 \beta 2 \mathrm{nAChRs}$ (Chatterjee et al., 2011; Mineur et al., 2011). CP-601932 and CP-601927 were safe in human clinical studies but CP-601932 was discontinued in Phase 2 due to a lack of efficacy compared with varenicline. The cytisine dimer, 1,2-bis-N-cytisinylethane (CC4) also acts as partial agonist with apparent selectivity for $\alpha 4 \beta 2$ and $\alpha 6 \beta 2 \mathrm{nAChRs}$ (Sala et al., 2013). In a zebrafish model, CC4 and CC26 reduced nicotineinduced self-administration and conditioned place preference (Ponzoni et al., 2014). Dianicline (SSR591813) is another cytisine derivative that was developed by Sanofi-Synthelabo Research, France as a partial agonist with higher affinity for $\alpha 4 \beta 2 \mathrm{nAChRs}$ than other $\mathrm{nAChR}$ subtypes. Dianicline increased extracellular dopamine levels in the NAc, and prevented nicotine withdrawal signs in rats (Cohen et al., 2003). Dianicline was well tolerated and reduced self-reported tobacco craving and withdrawal symptoms. However, it did not increase cigarette smoking abstinence rates and was therefore discontinued in Phase 3 due to a lack of efficacy (end of treatment odds ratio of 1.2; Rollema et al., 2010; Tonstad et al., 2011).

\section{ABT-418 and ABT-089}

For more than two decades, Abbott has been investing heavily in the development of safe and effective ligands to target neuronal nAChRs for the treatment of a variety of neuropathologies and for smoking cessation (Arneric et al., 2007). This led to the introduction of a series of $\mathrm{nAChR}$ agonists and partial agonists including ABT-418 and ABT-089. ABT-418 is a full $\mathrm{nAChR}$ agonist with apparent selectivity for the neuronal $\mathrm{nAChR}$ especially the $\alpha 4 \beta 2$ subtype (Decker et al., 1994). ABT-418 is 3-10 fold more potent than nicotine in enhancing learning and memory. It has anxiolytic-like effects, a lower potency than nicotine in enhancing dopamine release, and much less propensity to cause side effects associated with nicotine (Arneric et al., 1994; Papke et al., 1997). ABT-418 was well tolerated and had no signs of abuse potential (Potter et al., 1999; Wilens et al., 1999) but its feasibility as smoking cessation aid has not been demonstrated in large scale clinical trials. ABT-089 has higher affinity for the $\alpha 4 \beta 2$ than the $\alpha 7 \mathrm{nAChR}$ subtype, enhanced ACh release and cognitive performance but was less potent and less efficacious than nicotine in stimulating dopamine release (Sullivan et al., 1997). In animal studies, acute administration of ABT-089 had no effect on nicotine self-administration but attenuated the reinstatement of nicotine-seeking behavior (Lee et al., 2014). While ABT-089 was safe and well tolerated in humans; its clinical efficacy as smoking cessation aid has not been yet demonstrated (Wilens et al., 2006; Apostol et al., 2012).

\section{Mecamylamine and other $\mathrm{nAChR}$ Antagonists}

Since the beneficial effect of NRTs could be attributed to functional antagonism, due to $\mathrm{nAChR}$ desensitization 
with continuous exposure to agonist, nAChR antagonists were exploited as smoking cessation aids (Dwoskin et al., 2004). Mecamylamine is a non-selective nAChRs competitive antagonist that inhibits nicotine-induced dopamine release from striatal slices in a concentration-dependent manner (Nickell et al., 2013). However, mecamylamine used alone or in combination with nicotine was no better than NRTs used alone in improving the chance of quitting smoking in a doubleblind randomized clinical trial (Glover et al., 2007). In recent preclinical studies, selective $\alpha 6$-containing $\mathrm{nAChR}$ antagonists such as $\alpha$-conotoxin PIA and BPiDI have been shown to reduce nicotine-induced DA release in striatal slices and to decrease nicotine self-administration in rats (Brunzell et al., 2010; Gotti et al., 2010; Wooters et al., 2011). These results provided evidence that selective inhibition of $\alpha 6$-containing $\mathrm{nAChRs}$ has potential therapeutic use for smoking cessation (Brunzell et al., 2014).

\section{Sazetidine A (a nAChR Silent Desensitizer)}

Sazetidine A represents a new class of nAChR ligands. It does not directly activate $\mathrm{nAChR}$, does not inhibit nicotine-induced $\mathrm{nAChR}$ activities and does not induce nAChR up-regulation. Instead, It desensitizes $\mathrm{nAChR}$ for prolonged periods without activation ("Silent desensitizer"; Xiao et al., 2006; Zwart et al., 2008; Hussmann et al., 2012). Sazetidine A binds with higher affinity at $\alpha 4 \beta 2$ than other $\mathrm{nAChR}$ subtypes and shows reduced withdrawal symptoms and nicotine self-administration (Levin et al., 2010), albeit with different functional and behavioral profiles than varenicline (Turner et al., 2013).

\section{THE POTENTIAL THERAPEUTIC USE OF nAChR ALLOSTERIC MODULATORS}

Selective targeting of nAChRs is a leading strategy for smoking cessation aid development, and there are sincere efforts to develop $\mathrm{nAChR}$ ligands with high selectivity for specific receptor subtypes. Nevertheless, nicotine and varenicline are the only FDA-approved nAChR ligands for smoking cessation (Hurst et al., 2013). The development of $\mathrm{nAChR}$ based therapeutics remains challenging, in large part, because of the presence of multiple neuronal nAChR subtypes in the reward pathway with unique roles in the development of nicotine addiction. The majority of currently pursued nAChRs therapeutics fall under the category of agonists, partial agonists or antagonists that bind to orthosteric (agonist binding) sites. Because neuronal nAChRs subtypes share conserved ACh binding sites, there have been difficulties developing clinically useful agonist/partial agonist with selectivity for a nAChR subtype. Furthermore, direct activation of neuronal nAChRs by orthosteric ligands is associated with alteration in cholinergic transmission due to prolonged activation and desensitization of nAChRs (Williams et al., 2011). Therefore, positive allosteric modulators (PAMs) of nAChRs were introduced as a novel class for nAChR-based therapeutics (Taly et al., 2009). PAMs do not bind to the ACh binding site or activate nAChRs in the absence of ACh. Rather, they potentiate ACh-induced response by increasing ACh potency, enhancing ACh efficacy and/or nAChR opening probability and have minimal effect on the patterns of brain cholinergic activities (Williams et al., 2011; Uteshev, 2014). As such, nAChR PAMs lack reinforcing actions of their own but replace the subjective reinforcement effect of nicotine. Thus, they reduce the need for tobacco intake with minimal abuse liability (Liu, 2013). Since PAMs binding site(s) are distinct from the evolutionarily conserved ACh binding sites, they exhibit greater structural diversity and are more likely to be exclusive to a nAChR subpopulation. As such, nAChR PAMs may provide the required specificity for developing novel compounds that target $\mathrm{nAChR}$ subtypes with complex subunit composition $(\alpha 4 \alpha 6 \beta 2 \beta 3, \alpha 6 \beta 2 \beta 3$ and $\alpha 6 \beta 2)$ that are expressed mainly in striatal dopaminergic neurons (Taly et al., 2009). In support of this notion, several available nAChR PAMs have displayed far greater $\mathrm{nAChR}$ subtype selectivity than agonists (Sala et al., 2005; Albrecht et al., 2008; Springer et al., 2008; Timmermann et al., 2012; Olsen et al., 2014). Examples of non-selective nAChR PAMs include physostigmine and galantha -mine and selective $\alpha 4 \beta 2$ nAChR PAMs include $\mathrm{dFBr}$ (desformylflustrabromine), NS9283 (3-[3-(pyridin-3-yl)-1,2,4oxadiazol-5-yl]benzonitrile, and CMPI (3-(2-chlorophenyl)5-(5-methyl-1-(piperidin-4-yl)-1H-pyrrazol-4-yl)isoxazole;

Figure 2). Galanthamine and physostigmine are used clinically as acetylcholinesterase inhibitors. They were among the first nAChRs allosteric potentiators to be identified (Maelicke et al., 2001). Galanthamine potentiates ACh-induced activities of nAChRs but not muscarinic acetylcholine receptors (Samochocki et al., 2003). Galanthamine has been shown to reduce nicotine-self administration behavior in rats (Liu, 2013) and to enhance dopaminergic neurotransmission in vivo via $\mathrm{nAChR}$ potentiation (Schilström et al., 2007). The lack of nAChR subtype selectivity hindered the use of physostigmine and galanthamine for smoking cessation but they are valuable pharmacology tools for studying the interaction of allosteric modulators with nAChRs. Physostigmine and galanthamine computational docking studies and photoaffinity labeling with $\left[{ }^{3} \mathrm{H}\right]$ physostigmine and $\left[{ }^{3} \mathrm{H}\right]$ galanthamine identified allosteric binding sites in the $\mathrm{nAChR}$ extracellular domain both at the agonist-binding ("canonical") and non-agonist binding "noncanonical" subunit interfaces (Luttmann et al., 2009; Hamouda et al., 2013). dFBr was isolated from the marine bryozoan Flustra foliacea (Peters et al., 2002) and its effect as neuronal nAChR PAM was demonstrated. dFBr enhanced ACh-currents in $\alpha 4 \beta 2 \mathrm{nAChR}$ but not $\alpha 7$ or $\alpha 3$-containing nAChRs (Sala et al., 2005; Kim et al., 2007). dFBr was also shown to block the inhibitory effect of $\beta$ Amyloid $\left(\mathrm{A} \beta_{1-42}\right)$ peptide on $\alpha 4 \beta 2 \mathrm{nAChR}$ (Pandya and Yakel, 2011). In rats, $\mathrm{dFBr}$ was shown to reduce intravenous nicotine self-administration without supporting self-administration behavior (Liu, 2013). CMPI and several other substituted piperidines have been identified as potent and selective $\alpha 4 \beta 2 \mathrm{nAChR}$ potentiators in high-throughput screening and lead optimization projects at Amgen Inc., (Albrecht et al., 2008; Springer et al., 2008). NS9283, developed at Neurosearch Inc., specifically enhances the potency of acetylcholine induced currents in $\alpha 4 \beta 2$ receptors with a $3 \alpha, 2 \beta$ subunit stoichiometry (Timmermann et al., 2012; Olsen et al., 2014) thus providing further selectivity for a subpopulation within the $\alpha 4 \beta 2 \mathrm{nAChR}$ subtype. 


\section{CONCLUSION}

Drugs that selectively target a subpopulation of nAChRs within the brain's nicotine reward pathway will have a great impact on the treatment of nicotine addiction. However, the design and development of novel nAChR orthosteric and allosteric ligands require: (1) an accurate mapping of anatomical distribution and delineation of functional contribution of various nAChRs; (2) precise understanding of the three dimensional structure of individual nAChR subtypes; (3) structural studies to illustrate drugs binding mode within the orthosteric binding site (e.g., Hansen et al., 2008; Bach et al., 2015). Such studies will provide structural information that may expand the chemical space in the development of novel partial agonists as a smoke cessation aids; and (4) structural studies to identify binding sites for nAChR

\section{REFERENCES}

Alberg, A. J., Shopland, D. R., and Cummings, K. M. (2014). The 2014 surgeon general's report: commemorating the 50th anniversary of the 1964 report of the advisory committee to the us surgeon general and updating the evidence on the health consequences of cigarette smoking. Am. J. Epidemiol. 179, 403-412. doi: 10.1093/aje/kwt335

Albrecht, B. K., Berry, V., Boezio, A. A., Cao, L., Clarkin, K., Guo, W., et al. (2008). Discovery and optimization of substituted piperidines as potent, selective, CNS-penetrant alpha4beta2 nicotinic acetylcholine receptor potentiators. Bioorg. Med. Chem. Lett. 18, 5209-5212. doi: 10.1016/j.bmcl.2008.08.080

Apostol, G., Abi-Saab, W., Kratochvil, C. J., Adler, L. A., Robieson, W. Z., Gault, L. M., et al. (2012). Efficacy and safety of the novel $\alpha_{4} \beta_{2}$ neuronal nicotinic receptor partial agonist ABT-089 in adults with attention-deficit/hyperactivity disorder: a randomized, double-blind, placebo-controlled crossover study. Psychopharmacology (Berl) 219, 715-725. doi: 10.1007/s00213-011-2393-2

Arneric, S. P., Holladay, M., and Williams, M. (2007). Neuronal nicotinic receptors: a perspective on two decades of drug discovery research. Biochem. Pharmacol. 74, 1092-1101. doi: 10.1016/j.bcp.2007.06.033

Arneric, S. P., Sullivan, J. P., Briggs, C. A., Donnelly-Roberts, D., Anderson, D. J., Raszkiewicz, J. L., et al. (1994). (S)-3-methyl-5-(1-methyl-2-pyrrolidinyl) isoxazole (ABT 418): a novel cholinergic ligand with cognition-enhancing and anxiolytic activities: I. In vitro characterization. J. Pharmacol. Exp. Ther. 270, 310-318.

Bach, T. B., Jensen, A. A., Petersen, J. G., Sørensen, T. E., Della Volpe, S., Liu, J., et al. (2015). Exploration of the molecular architecture of the orthosteric binding site in the $\alpha 4 \beta 2$ nicotinic acetylcholine receptor with analogs of 3-(dimethylamino)butyl dimethylcarbamate (DMABC) and 1-(pyridin-3-yl)1,4-diazepane. Eur. J. Med. Chem. 102, 425-444. doi: 10.1016/j.ejmech.2015. 07.024

Benwell, M. E., Balfour, D. J., and Anderson, J. M. (1988). Evidence that tobacco smoking increases the density of (-)-[3H]nicotine binding sites in human brain. J. Neurochem. 50, 1243-1247. doi: 10.1111/j.1471-4159.1988.tb10600.x

Bierut, L. J., Stitzel, J. A., Wang, J. C., Hinrichs, A. L., Grucza, R. A., Xuei, X., et al. (2008). Variants in nicotinic receptors and risk for nicotine dependance. Am. J. Psychiatry 165, 1163-1171. doi: 10.1176/appi.ajp.2008.07111711

Brunzell, D. H., Boschen, K. E., Hendrick, E. S., Beardsley, P. M., and McIntosh, J. M. (2010). Alpha-conotoxin MII-sensitive nicotinic acetylcholine receptors in the nucleus accumbens shell regulate progressive ratio responding maintained by nicotine. Neuropsychopharmacology 35, 665-673. doi: 10 . 1038/npp.2009.171

Brunzell, D. H., McIntosh, J. M., and Papke, R. (2014). Diverse strategies targeting 7 homomeric and 6 beta2 ${ }^{*}$ heteromeric nicotinic acetylcholine receptors for smoking cessation. Ann. N Y Acad. Sci. 1327, 27-45. doi: 10.1111/nyas.12421

Cassels, B. K., Bermúdez, I., Dajas, F., Abin-Carriquiry, J. A., and Wonnacott, S. (2005). From ligand design to therapeutic efficacy: the challenge for nicotinic receptor research. Drug Discov. Today 10, 1657-1665. doi: 10.1016/s13596446(05)03665-2
PAMs (e.g., Seo et al., 2009; Olsen et al., 2013; Hamouda et al., 2015) and to understand the structural bases of PAM subtype selectivity. Such studies have the potential to identify novel allosteric sites that are unique to $\alpha 6 \beta 2$ and $\alpha 4 \beta 2$-containing $\mathrm{nAChRs}$ and to facilitate the development of novel nAChR based therapeutics for smoking cessation.

\section{AUTHOR CONTRIBUTIONS}

Contributed to writing of manuscript: TSM, SSJ and AKH.

\section{ACKNOWLEDGMENTS}

TSM and AKH are supported by a Texas A\&M Health Sciences Center Faculty development fund to AKH.

Changeux, J.-P. (2010). Nicotine addiction and nicotinic receptors: lessons from genetically modified mice. Nat. Rev. Neurosci. 11, 389-401. doi: 10. 1038/nrn2849

Chatterjee, S., Steensland, P., Simms, J. A., Holgate, J., Coe, J. W., Hurst, R. S., et al. (2011). Partial agonists of the $\alpha 3 \beta 4^{*}$ neuronal nicotinic acetylcholine receptor reduce ethanol consumption and seeking in rats. Neuropsychopharmacology 36, 603-615. doi: 10.1038/npp.2010.191

Coe, J. W., Brooks, P. R., Vetelino, M. G., Wirtz, M. C., Arnold, E. P., Huang, J., et al. (2005a). Varenicline: an alpha4beta2 nicotinic receptor partial agonist for smoking cessation. J. Med. Chem. 48, 3474-3477. doi: 10.1021/jm0 50069 n

Coe, J. W., Vetelino, M. G., Bashore, C. G., Wirtz, M. C., Brooks, P. R., Arnold, E. P., et al. (2005b). In pursuit of alpha4beta2 nicotinic receptor partial agonists for smoking cessation: carbon analogs of (-)-cytisine. Bioorg. Med. Chem. Lett. 15, 2974-2979. doi: 10.1016/j.bmcl.2005.04.036

Cohen, C., Bergis, O. E., Galli, F., Lochead, A. W., Jegham, S., Biton, B., et al. (2003). SSR591813, a novel selective and partial alpha4beta2 nicotinic receptor agonist with potential as an aid to smoking cessation. J. Pharmacol. Exp. Ther. 306, 407-420. doi: 10.1124/jpet.103.049262

Decker, M. W., Brioni, J. D., Sullivan, J. P., Buckley, M. J., Radek, R. J., Raszkiewicz J. L., et al. (1994). (S)-3-methyl-5-(1-methyl-2-pyrrolidinyl)isoxazole (ABT 418): a novel cholinergic ligand with cognition-enhancing and anxiolytic activities: II. In vivo characterization. J. Pharmacol. Exp. Ther. 270, 319-328.

Dome, P., Lazary, J., Kalapos, M. P., and Rihmer, Z. (2010). Smoking, nicotine and neuropsychiatric disorders. Neurosci. Behav. Rev. 34, 295-342. doi: 10.1016/j. neubiorev.2009.07.013

Drenan, R. M., Grady, S. R., Whiteaker, P., McClure-Begley, T., McKinney, S., Miwa, J. M., et al. (2008). In vivo activation of midbrain dopamine neurons via sensitized, high-affinity alpha 6 nicotinic acetylcholine receptors. Neuron 60, 123-136. doi: 10.1016/j.neuron.2008.09.009

Dwoskin, L. P., Rauhut, A. S., King-Pospisil, K. A., and Bardo, M. T. (2006). Review of the pharmacology and clinical profile of bupropion, an antidepressant and tobacco use cessation agent. CNS Drug Rev. 12, 178-207. doi: 10.1111/j.15273458.2006.00178.x

Dwoskin, L. P., Sumithran, S. P., Zhu, J., Deaciuc, A. G., Ayers, J. T., and Crooks, P. A. (2004). Subtype-selective nicotinic receptor antagonists: potential as tobacco use cessation agents. Bioorg. Med. Chem. Lett. 14, 1863-1867. doi: 10. 1016/j.bmcl.2003.10.073

Ebbert, J. O., Hatsukami, D. K., Croghan, I. T., Schroeder, D. R., Allen, S. S., Hays, J. T., et al. (2014). Combination varenicline and bupropion SR for tobaccodependance treatment in cigarette smokers. JAMA 311, 155-163. doi: 10. 1001/jama.2013.283185

Erhardt, S., Schwieler, L., and Engberg, G. (2002). Excitatory and inhibitory responses of dopamine neurons in the ventral tegmental area to nicotine. Synapse 43, 227-237. doi: 10.1002/syn.10044

Etter, J. F. (2006). Cytisine for smoking cessation: a literature review and a metaanalysis. Arch. Intern. Med. 166, 1553-1559. doi: 10.1001/archinte.166.15.1553 
Evins, A. E., Cather, C., and Laffer, A. (2015). Treatment of tobacco use disorders in smokers with serious mental illness: toward clinical best practices. Harv. Rev. Psychiatry 23, 90-98. doi: 10.1097/hrp.0000000000000063

Evins, A. E., Cather, C., Pratt, S. A., Pachas, G. N., Hoeppner, S. S., Goff, D. C., et al. (2014). Maintenance treatment with varenicline for smoking cessation in patients with schizophrenia and bipolar disorder: a randomized clinical trial. JAMA 311, 145-154. doi: 10.1001/jama.2013.285113

Exley, R., Clements, M. A., Hartung, H., McIntosh, J. M., and Cragg, S. J. (2008). Alpha6-containing nicotinic acetylcholine receptors dominate the nicotine control of dopamine neurotransmission in nucleus accumbens. Neuropsychopharmacology 33, 2158-2166. doi: 10.1038/sj.npp.1301617

Exley, R., McIntosh, J. M., Marks, M. J., Maskos, U., and Cragg, S. J. (2012). Striatal $\alpha 5$ nicotinic receptor subunit regulates dopamine transmission in dorsal striatum. J. Neurosci. 32, 2352-2356. doi: 10.1523/JNEUROSCI.4985-11. 2012

Flores, C. M., Rogers, S. W., Pabreza, L. A., Wolfe, B. B., and Kellar, K. J. (1992). A subtype of nicotinic cholinergic receptor in rat brain is composed of alpha 4 and beta 2 subunits and is up-regulated by chronic nicotine treatment. Mol. Pharmacol. 41, 31-37.

Frahm, S., Slimak, M. A., Ferrarese, L., Santos-Torres, J., Antolin-Fontes, B., Auer, S., et al. (2011). Aversion to nicotine is regulated by the balanced activity of $\beta 4$ and $\alpha 5$ nicotinic receptor subunits in the medial habenula. Neuron $70,522-535$. doi: 10.1016/j.neuron.2011.04.013

Glover, E. D., Laflin, M. T., Schuh, K. J., Schuh, L. M., Nides, M., Christen, A. G., et al. (2007). A randomized, controlled trial to assess the efficacy and safety of a transdermal delivery system of nicotine/mecamylamine in cigarette smokers. Addiction 102, 795-802. doi: 10.1111/j.1360-0443.2007.01763.x

Gonzales, D., Rennard, S. I., Nides, M., Oncken, C., Azoulay, S., Billing, C. B., et al. (2006). Varenicline, an alpha4beta2 nicotinic acetylcholine receptor partial agonist, vs. sustained-release bupropion and placebo for smoking cessation: a randomized controlled trial. JAMA 296, 47-55. doi: 10.1001/jama.296.1.47

Gotti, C., and Clementi, F. (2004). Neuronal nicotinic receptors: from structure to pathology. Prog. Neurobiol. 74, 363-396. doi: 10.1016/j.pneurobio.2004.09.006

Gotti, C., Guiducci, S., Tedesco, V., Corbioli, S., Zanetti, L., Moretti, M., et al. (2010). Nicotinic acetylcholine receptors in the mesolimbic pathway: primary role of ventral tegmental area alpha6beta2* receptors in mediating systemic nicotine effects on dopamine release, locomotion and reinforcement. J. Neurosci. 30, 5311-5325. doi: 10.1523/JNEUROSCI.5095-09.2010

Gracem, A. A., and Bunney, B. S. (1984). The control of firing pattern in nigral dopamine neurons: single spike firing. J. Neurosci. 4, 2866-2876.

Hamouda, A. K., Jayakar, S. S., Chiara, D. C., and Cohen, J. B. (2014). Photoaffinity labeling of nicotinic receptors: diversity of drug binding sites! J. Mol. Neurosci. 53, 480-486. doi: 10.1007/s12031-013-0150-1

Hamouda, A. K., Kimm, T., and Cohen, J. B. (2013). Physostigmine and galanthamine bind in the presence of agonist at the canonical and noncanonical subunit interfaces of a nicotinic acetylcholine receptor. J. Neurosci. 33, 485-494. doi: 10.1523/JNEUROSCI.3483-12.2013

Hamouda, A. K., Wang, Z. J., Stewart, D. S., Jain, A. D., Glennon, R. A., and Cohen, J. B. (2015). Desformylflustrabromine $(\mathrm{dFBr})$ and $[3 \mathrm{H}] \mathrm{dFBr}-\mathrm{Labeled}$ binding sites in a nicotinic acetylcholine receptor. Mol. Pharmacol. 88, 1-11. doi: 10. 1124/mol.115.098913

Hansen, C. P., Jensen, A. A., Christensen, J. K., Balle, T., Liljefors, T., and Frølund, B. (2008). Novel acetylcholine and carbamoylcholine analogs: development of a functionally selective alpha4beta2 nicotinic acetylcholine receptor agonist. J. Med. Chem. 51, 7380-7395. doi: 10.1021/jm701625v

Hurst, R., Rollema, H., and Bertrand, D. (2013). Nicotinic acetylcholine receptors: From basic science to therapeutics. Pharmacol. Ther. 137, 22-54. doi: 10.1016/j. pharmthera.08.012

Hussmann, G. P., Turner, J. R., Lomazzo, E., Venkatesh, R., Cousins, V., Xiao, Y., et al. (2012). Chronic sazetidine-A at behaviorally active doses does not increase nicotinic cholinergic receptors in rodent brain. J. Pharmacol. Exp. Ther. 343, 441-450. doi: 10.1124/jpet.112.198085

Igari, M., Alexander, J. C., Ji, Y., Qi, X., Papke, R. L., and Bruijnzeel, A. W. (2014). Varenicline and cytisine diminish the dysphoric-like state associated with spontaneous nicotine withdrawal in rats. Neuropsychopharmacology 39, 455-465. doi: 10.1038/npp.2013.216

Jensen, A. A., Frølund, B., Liljefors, T., and Krogsgaard-Larsen, P. (2005). Neuronal nicotinic acetylcholine receptors: structural revelations, target identifications and therapeutic inspirations. J. Med. Chem. 48, 4705-4745. doi: 10.1002/chin.200541286

Jin, X., Bermudez, I., and Steinbach, J. H. (2014). The nicotinic $\alpha 5$ subunit can replace either an acetylcholine-binding or nonbinding subunit in the $\alpha 4 \beta 2^{*}$ neuronal nicotinic receptor. Mol. Pharmacol. 85, 11-17. doi: 10.1124/mol.113. 089979

Kalamida, D., Poulas, K., Avramopoulou, V., Fostieri, E., Lagoumintzis, G., Lazaridis, K., et al. (2007). Muscle and neuronal nicotinic acetylcholine receptors structure, function and pathogenicity. FEBS J. 274, 3799-3845. doi: 10.1111/j.1742-4658.2007.05935.x

Kim, J. S., Padnya, A., Weltzin, M., Edmonds, B. W., Schulte, M. K., and Glennon, R. A. (2007). Synthesis of desformylflustrabromine and its evaluation as an alpha4beta2 and alpha7 nACh receptor modulator. Bioorg. Med. Chem. Lett. 17, 4855-4860. doi: 10.1016/j.bmcl.2007.06.047

Klink, R., de Kerchove d'Exaerde, A., Zoli, M., and Changeux, J. P. (2001). Molecular and physiological diversity of nicotinic acetylcholine receptors in the midbrain dopaminergic nuclei. J. Neurosci. 21, 1452-1463.

Laviolette, S. R., and van der Kooy, D. (2004). The neurobiology of nicotine addiction: bridging the gap from molecules to behavior. Nat. Rev. Neurosci. 5 , 55-65. doi: 10.1038/nrn1298

Leaviss, J., Sullivan, W., Ren, S., Everson-Hock, E., Stevenson, M., Stevens, J. W., et al. (2014). What is the clinical effectiveness and cost-effectiveness of cytisine compared with varenicline for smoking cessation? A systematic review and economic evaluation. Health Technol. Assess. 18, 1-120. doi: 10.3310/hta18330

Lee, A. M., Arreola, A. C., Kimmey, B. A., and Schmidt, H. D. (2014). Administration of the nicotinic acetylcholine receptor agonists ABT-089 and ABT-107 attenuates the reinstatement of nicotine-seeking behavior in rats. Behav. Brain Res. 274, 168-175. doi: 10.1016/j.bbr.2014.08.016

Lee, J. H., Jones, P. G., Bybee, K., and O'Keefe, J. H. (2008). Longer course of varenicline therapy improves smoking cessation rates. Prev. Cardiol. 11, 210-214. doi: 10.1111/j.1751-7141.2008.00003.x

Lerman, C., LeSage, M., Perkins, K. A., O’Malley, S. S., Siegel, S. J., Benowitz, N. L., et al. (2007). Translational research in medication development for nicotine dependance. Nat. Rev. Drug Discov. 6, 746-762. doi: 10.1038/ $\operatorname{nrd} 2361$

Levin, E. D., Rezvani, A. H., Xiao, Y., Slade, S., Cauley, M., Wells, C., et al. (2010). Sazetidine-A, a selective alpha4beta2 nicotinic receptor desensitizing agent and partial agonist, reduces nicotine self-administration in rats. J. Pharmacol. Exp. Ther. 332, 933-939. doi: 10.1124/jpet.109.162073

Liu, X. (2013). Positive allosteric modulation of $\alpha 4 \beta 2$ nicotinic acetylcholine receptors as a new approach to smoking reduction: evidence from a rat model of nicotine self-administration. Psychopharmacology (Berl) 230, 203-213. doi: 10. 1007/s00213-013-3145-2

Luttmann, E., Ludwig, J., Höffle-Maas, A., Samochocki, M., Maelicke, A., and Fels, G. (2009). Structural model for the binding sites of allosterically potentiating ligands on nicotinic acetylcholine receptors. Chem. Med. Chem 4, 1874-1882. doi: $10.1002 / \mathrm{cmdc} .200900320$

Maelicke, A., Samochocki, M., Jostock, R., Fehrenbacher, A., Ludwig, J., Albuquerque, E. X., et al. (2001). Allosteric sensitization of nicotinic receptors by galantamine, a new treatment strategy for Alzheimer's disease. Biol. Psychiatry 49, 279-288. doi: 10.1016/s0006-3223(00)01109-4

Mansvelder, H. D., Keath, J. R., and McGehee, D. S. (2002). Synaptic mechanisms underlie nicotine-induced excitability of brain reward areas. Neuron 33, 905-919. doi: 10.1016/s0896-6273(02)00625-6

Marubio, L. M., del Mar Arroyo-Jimenez, M., Cordero-Erausquin, M., Léna, C., Le Novère, N., de Kerchove d'Exaerde, A., et al. (1999). Reduced antinociception in mice lacking neuronal nicotinic receptor subunits. Nature 398, 805-810. doi: 10.1038/19756

Maskos, U., Molles, B. E., Pons, S., Besson, M., Guiard, B. P., Guilloux, J.-P., et al. (2005). Nicotine reinforcement and cognition restored by targeted expression of nicotinic receptors. Nature 436, 103-107. doi: 10.1038/nature03694

Mihalak, K. B., Carroll, F. I., and Luetje, C. W. (2006). Varenicline is a partial agonist at alpha4beta2 and a full agonist at alpha7 neuronal nicotinic receptors. Mol. Pharmacol. 70, 801-805. doi: 10.1124/mol.106.025130

Mineur, Y. S., Einstein, E. B., Seymour, P. A., Coe, J. W., O’neill, B. T., Rollema, H., et al. (2011). $\alpha 4 \beta 2$ nicotinic acetylcholine receptor partial agonists with low intrinsic efficacy have antidepressant-like properties. Behav. Pharmacol. 22, 291-299. doi: 10.1097/FBP.0b013e328347546d 
Nickell, J. R., Grinevich, V. P., Siripurapu, K. B., Smith, A. M., and Dwoskin, L. P. (2013). Potential therapeutic uses of mecamylamine and its stereoisomers. Pharmacol. Biochem. Behav. 108, 28-43. doi: 10.1016/j.pbb.2013.04.005

Nides, M., Glover, E. D., Reus, V. I., Christen, A. G., Make, B. J., Billing, C. B. Jr., et al. (2008). Varenicline versus bupropion SR or placebo for smoking cessation: a pooled analysis. Am. J. Health Behav. 32, 664-675. doi: 10. 5555/ajhb.2008.32.6.664

Nisell, M., Nomikos, G. G., and Svensson, T. H. (1994). Infusion of nicotine in the ventral tegmental area or the nucleus accumbens of the rat differentially affects accumbal dopamine release. Pharmacol. Toxicol. 75, 348-352. doi: 10.1111/j. 1600-0773.1994.tb00373.x

Olsen, J. A., Ahring, P. K., Kastrup, J. S., Gajhede, M., and Balle, T. (2014). Structural and functional studies of the modulator NS9283 reveal agonist-like mechanism of action at alpha4beta2 nicotinic acetylcholine receptors. J. Biol. Chem. 289, 24911-24921. doi: 10.1074/jbc.M114.568097

Olsen, J. A., Kastrup, J. S., Peters, D., Gajhede, M., Balle, T., and Ahring, P. K. (2013). Two distinct allosteric binding sites at $\alpha 4 \beta 2$ nicotinic acetylcholine receptors revealed by NS206 and NS9283 give unique insights to binding activity-associated linkage at Cys-loop receptors. J. Biol. Chem. 288, 35997-36006. doi: 10.1074/jbc.M113.498618

Pandya, A., and Yakel, J. L. (2011). Allosteric modulator Desformylflustrabromine relieves the inhibition of $\alpha 2 \beta 2$ and $\alpha 4 \beta 2$ nicotinic acetylcholine receptors by $\beta$-amyloid(1-42) peptide. J. Mol. Neurosci. 45, 42-47. doi: 10.1007/s12031-0119509-3

Papke, R. L., Thinschmidt, J. S., Moulton, B. A., Meyer, E. M., and Poirier, A. (1997). Activation and inhibition of rat neuronal nicotinic receptors by ABT418. Br. J. Pharmacol. 120, 429-438. doi: 10.1038/sj.bjp.0700930

Peters, L., König, G. M., Terlau, H., and Wright, A. D. (2002). Four new bromotryptamine derivatives from the marine bryozoan Flustra foliacea. J. Nat. Prod. 65, 1633-1637. doi: 10.1021/np0105984

Picciotto, M. R., Zoli, M., Léna, C., Bessis, A., Lallemand, Y., Le Novère, N., et al. (1995). Abnormal avoidance learning in mice lacking functional highaffinity nicotine receptor in the brain. Nature 374, 65-67. doi: 10.1038/37 $4065 \mathrm{a} 0$

Picciotto, M. R., Zoli, M., Rimondini, R., Léna, C., Marubio, L. M., Pich, E. M., et al. (1998). Acetylcholine receptors containing the beta2 subunit are involved in the reinforcing properties of nicotine. Nature 391, 173-177. doi: 10.1038/ 34413

Ponzoni, L., Braida, D., Pucci, L., Andrea, D., Fasoli, F., Manfredi, I., et al. (2014). The cytisine derivatives, CC4 and CC26, reduce nicotine-induced conditioned place preference in zebrafish by acting on heteromeric neuronal nicotinic acetylcholine receptors. Psychopharmacology (Berl) 231, 4681-4693. doi: 10. 1007/s00213-014-3619-x

Potter, A., Corwin, J., Lang, J., Piasecki, M., Lenox, R., and Newhouse, P. A. (1999). Acute effects of the selective cholinergic channel activator (nicotinic agonist) ABT-418 in Alzheimer's disease. Psychopharmacology (Berl) 142, 334-342. doi: $10.1007 / \mathrm{s} 002130050897$

Prochaska, J. J., Das, S., and Benowitz, N. L. (2013). Cytisine, the world's oldest smoking cessation aid. BMJ 347:f5198. doi: 10.1136/bmj.f5198

Reus, V. I., Obach, R. S., Coe, J. W., Faessel, H., Rollema, H., Watsky, E., et al. (2007). Varenicline: new treatment with efficacy in smoking cessation. Drugs Today (Barc) 43, 65-75. doi: 10.1358/dot.2007.43.2.1069956

Rollema, H., Chambers, L. K., Coe, J. W., Glowa, J., Hurst, R. S., Lebel, L. A., et al. (2007). Pharmacological profile of the alpha4beta2 nicotinic acetylcholine receptor partial agonist varenicline, an effective smoking cessation aid. Neuropharmacology 52, 985-994. doi: 10.1016/j.neuropharm.2006. 10.016

Rollema, H., Shrikhande, A., Ward, K. M., Tingley, F. D. IIIrd, Coe, J. W., O’Niel, B. T., et al. (2010). Pre-clinical properties of the alpha4beta2 nicotinic acetylcholine receptor partial agonist varenicline, cytisine and dianicline translate to clinical efficacy for nicotine dependance. Br. J. Pharmacol. 160, 334-345. doi: 10.1111/j.1476-5381.2010.00682.x

Rose, J. E., Behm, F. M., Westman, E. C., and Coleman, R. E. (1999). Arterial nicotine kinetics during cigarette smoking and intravenous nicotine administration: implications for addiction. Drug Alcohol Depend. 56, 99-107. doi: 10.1016/s0376-8716(99)00025-3

Sabey, K., Paradiso, K., Zhang, J., and Steinbach, J. H. (1999). Ligand binding and activation of rat nicotinic alpha4beta2 receptors stably expressed in HEK293 cells. Mol. Pharmacol. 55, 58-66.
Sala, M., Braida, D., Pucci, L., Manfredi, I., Marks, M. J., Wageman, C. R., et al. (2013). CC4, a dimer of cytisine, is a selective partial agonist at $\alpha 4 \beta 2 / \alpha 6 \beta 2 \mathrm{nAChR}$ with improved selectivity for tobacco smoking cessation. Br. J. Pharmacol. 168, 835-849. doi: 10.1111/j.1476-5381.2012.02204.x

Sala, F., Mulet, J., Reddy, K. P., Bernal, J. A., Wikman, P., Valor, L. M., et al. (2005). Potentiation of human alpha4beta2 neuronal nicotinic receptors by a Flustra foliacea metabolite. Neurosci. Lett. 373, 144-149. doi: 10.1016/j.neulet.2004. 10.002

Samochocki, M., Höffle, A., Fehrenbacher, A., Jostock, R., Ludwig, J., Christner, C., et al. (2003). Galantamine is an allosterically potentiating ligand of neuronal nicotinic but not of muscarinic acetylcholine receptors. J. Pharmacol. Exp. Ther. 305, 1024-1036. doi: 10.1124/jpet.102.045773

Schilström, B., Ivanov, V. B., Wiker, C., and Svensson, T. H. (2007). Galantamine enhances dopaminergic neurotransmission in vivo via allosteric potentiation of nicotinic acetylcholine receptors. Neuropsychopharmacology 32, 43-53. doi: 10. 1038/sj.npp.1301087

Seo, S., Henry, J. T., Lewis, A. H., Wang, N., and Levandoski, M. M. (2009). The positive allosteric modulator morantel binds at noncanonical subunit interfaces of neuronal nicotinic acetylcholine receptors. J. Neurosci. 29, 8734-8742. doi: 10.1523/JNEUROSCI.1859-09.2009

Slemmer, J. E., Martin, B. R., and Damaj, M. I. (2000). Bupropion is a nicotinic antagonist. J. Pharmacol. Exp. Ther. 295, 321-327. doi: 0022-3565/00/2951$0321 \$ 03.00 / 0$

Springer, S. K., Woodin, K. S., Berry, V., Boezio, A. A., Cao, L., Clarkin, K., et al. (2008). Synthesis and activity of substituted carbamates as potentiators of the alpha4 beta2 nicotinic acetylcholine receptor. Bioorg. Med. Chem. Lett. 18, 5643-5647. doi: 10.1016/j.bmcl.2008.08.092

Stead, L. F., Perera, R., Bullen, C., Mant, D., and Lancaster, T. (2008). Nicotine replacement therapy for smoking cessation. Cochrane Database Syst. Rev. 1:CD000146. doi: 10.1002/14651858.CD000146

Sullivan, J. P., Donnelly-Roberts, D., Briggs, C. A., Anderson, D. J., Gopalakrishnan, M., Xue, I. C., et al. (1997). ABT-089 [2-methyl-3-(2(S)-pyrrolidinylmethoxy)pyridine]: I A potent and selective cholinergic channel modulator with neuroprotective properties. J. Pharmacol. Exp. Ther. 283, 235-246. doi: 10.1002/(sici)1098-2299(199703)40:3<259::aid-ddr6>3.3. co; $2-x$

Syad, B. A., and Chaudhari, K. (2013). Smoking cessation drug market. Nat. Rev. Drug Discov. 12, 97-98. doi: 10.1038/nrd3914

Taly, A., Corringer, P. J., Guedin, D., Lestage, P., and Changeux, J. P. (2009). Nicotinic receptors: allosteric transitions and therapeutic targets in the nervous system. Nat. Rev. Drug Discov. 8, 733-750. doi: 10.1038/nrd2927

Timmermann, D. B., Sandager-Nielsen, K., Dyhring, T., Smith, M., Jacobsen, A. M., Nielsen, E. Ø., et al. (2012). Augmentation of cognitive function by NS9283, a stoichiometry-dependent positive allosteric modulator of $\alpha 2$ and $\alpha 4$-containing nicotinic acetylcholine receptors. Br. J. Pharmacol. 167, 164-182. doi: 10.1111/j.1476-5381.2012.01989.x

Tonstad, S., Holme, I., and Tønnesen, P. (2011). Dianicline, a novel $\alpha 4 \beta 2$ nicotinic acetylcholine receptor partial agonist, for smoking cessation: a randomized placebo-controlled clinical trial. Nicotine Tob. Res. 13, 1-6. doi: 10. 1093/ntr/ntq191

Tonstad, S., Tønnesen, P., Hajek, P., Williams, K. E., Billing, C. B., and Reeves, K. R. (2006). Effect of maintenance therapy with varenicline on smoking cessation: a randomized controlled trial. JAMA 296, 64-71. doi: 10.1001/jama. 296.1.64

Turner, J. R., Wilkinson, D. S., Poole, R. L., Gould, T. J., Carlson, G. C., and Blendy, J. A. (2013). Divergent functional effects of sazetidine-a and varenicline during nicotine withdrawal. Neuropsychopharmacology 38, 2035-2047. doi: 10. 1038/npp.2013.105

Uteshev, V. V. (2014). The therapeutic promise of positive allosteric modulation of nicotinic receptors. Eur. J. Pharmacol. 727, 181-185. doi: 10.1016/j.ejphar. 2014.01.072

Walker, N., Howe, C., Glover, M., McRobbie, H., Barnes, J., Nosa, V., et al. (2014). Cytisine versus nicotine for smoking cessation. N. Engl. J. Med. 371, 2353-2362. doi: 10.1056/NEJMoa1407764

West, R., Zatonski, W., Cedzynska, M., Lewandowska, D., Pazik, J., Aveyard, P., et al. (2011). Placebo-controlled trial of cytisine for smoking cessation. N. Engl. J. Med. 365, 1193-1200. doi: 10.1056/NEJMoa1102035

Wilens, T. E., Biederman, J., Spencer, T. J., Bostic, J., Prince, J., Monuteaux, M. C., et al. (1999). A pilot controlled clinical trial of ABT-418, a cholinergic agonist, 
in the treatment of adults with attention deficit hyperactivity disorder. Am. J. Psychiatry 156, 1931-1937.

Wilens, T. E., Verlinden, M. H., Adler, L. A., Wozniak, P. J., and West, S. A. (2006). ABT-089, a neuronal nicotinic receptor partial agonist, for the treatment of attention-deficit/hyperactivity disorder in adults: results of a pilot study. Biol. Psychiatry 59, 1065-1070. doi: 10.1016/j.biopsych.2005. 10.029

Williams, D. K., Wang, J., and Papke, R. L. (2011). Positive allosteric modulators as an approach to nicotinic acetylcholine receptor-targeted therapeutics: advantages and limitations. Biochem. Pharmacol. 82, 915-930. doi: 10.1016/j. bcp.2011.05.001

Wonnacott, S., Sidhpura, N., and Balfour, D. J. K. (2005). Nicotine: from molecular mechanisms to behavior. Curr. Opin. Pharmacol. 5, 53-59. doi: 10.1016/j.coph. 2004.12.002

Wooters, T. E., Smith, A. M., Pivavarchyk, M., Siripurapu, K. B., McIntosh, J. M., Zhang, Z., et al. (2011). bPiDI: a novel selective alpha6beta2* nicotinic receptor antagonist and preclinical candidate treatment for nicotine abuse. Br. J. Pharmacol. 163, 346-357. doi: 10.1111/j.1476-5381.2011. 01220.x

Xiao, Y., Fan, H., Musachio, J. L., Wei, Z. L., Chellappan, S. K., Kozikowski, A. P., et al. (2006). Sazetidine-A, a novel ligand that desensitizes alpha4beta2 nicotinic acetylcholine receptors without activating them. Mol. Pharmacol. 70, 1454-1460. doi: 10.1124/mol.106.027318

Zhao-Shea, R., Liu, L., Soll, L. G., Improgo, M. R., Meyers, E. E., McIntosh, J. M., et al. (2011). Nicotine-mediated activation of dopaminergic neurons in distinct regions of the ventral tegmental area. Neuropsychopharmacology 36, 1021-1032. doi: 10.1038/npp.2010.240

Zwart, R., Carbone, A. L., Moroni, M., Bermudez, I., Mogg, A. J., Folly, E. A., et al. (2008). Sazetidine-A is a potent and selective agonist at native and recombinant alpha4 beta2 nicotinic acetylcholine receptors. Mol. Pharmacol. 73, 1838-18343. doi: 10.1124/mol.108.045104

Conflict of Interest Statement: The authors declare that the research was conducted in the absence of any commercial or financial relationships that could be construed as a potential conflict of interest.

Copyright (c) 2015 Mohamed, Jayakar and Hamouda. This is an open-access article distributed under the terms of the Creative Commons Attribution License (CC BY). The use, distribution and reproduction in other forums is permitted, provided the original author(s) or licensor are credited and that the original publication in this journal is cited, in accordance with accepted academic practice. No use, distribution or reproduction is permitted which does not comply with these terms. 